\title{
ANALISIS KEMAMPUAN PEMECAHAN MASALAH MATEMATIS SISWA DALAM MENYELESAIKAN SOAL CERITA
}

\author{
Ilhamsyah $^{1 *}$ \\ Ahmad Syafii ${ }^{2}$ \\ Irwan $\mathrm{Akib}^{3}$ \\ 1,2,3 Universitas Muhammadiyah Makassar, Makassar, Indonesia \\ ilhamsyah@unismuh.ac.id ${ }^{*}$ \\ ahmad2487.a2@gmail.com² \\ irwanakib863@gmail.com ${ }^{3}$
}

\begin{abstract}
Abstrak
Penelitian ini bertujuan untuk mendeskripsikan tingkat kemampuan pemecahan masalah siswa kelas VIII.B SMP Negeri 1 Bangkala Barat dalam menyelesaikan soal cerita pola bilangan. Jenis Penelitian ini merupakan penelitian kualitatif yang dirancang untuk mengetahui kemampuan pemecahan masalah matematis siswa dalam pokok bahasan pola bilangan. Teknik pengumplan data berupa tes dan wawancara. Instrumen yang digunakan berupa tes kemampuan pemecahan masalah yang berjumlah 3 soal. Wawancara dilakukan untuk lebih menggali kemampuan pemecahan masalah siswa. Subjek penelitian terdiri dari 1 siswa kategori tinggi, 1 siswa kategori sedang dan 1 siswa kategori rendah. Hasil penelitian menunjukkan bahwa (1) Siswa pada kategori tinggi dalam mengerjakan soal cerita pola bilangan mampu memahami masalah dengan baik, mampu menyusun rencana penyelesaian dan melaksanakan dengan langkah-langkah penyelesaian yang tepat, serta mengevaluasi atau memeriksa kembali jawaban sebelum membuat kesimpulan atau interpretasi. (2) Siswa pada kategori sedang mampu memahami soal dengan cukup baik, namun tidak menuliskan informasi yang diketahui dan hal apa yang ditanyakan ketika menjawab soal cerita pola bilangan, mampu menyusun rencana dan melaksanakan rencana penyelesaian sesuai dengan langkah penyelesaian dan aturan operasi hitung campuran dengan tepat. (3) Siswa pada kategori rendah tidak mampu memahami soal cerita pola bilangan, tidak mampu merencanakan dan melaksanakan penyelesaian, serta tidak mampu mengevaluasi dan menginterpretasi jawaban yang diperoleh.
\end{abstract}

Kata Kunci: Kemampuan pemecahan masalah, Soal cerita, SMP Negeri 1 Bangkala Barat.

\section{Diterbitkan Oleh:}

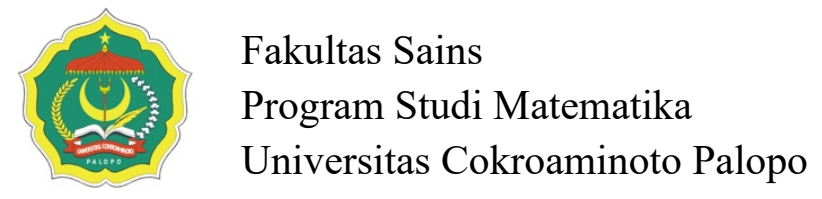

Copyright (C) 2021 The Author (s)

This article is licensed under CC BY 4.0 License

\section{$(\mathrm{cc}) \mathrm{BY}$}




\section{ANALISIS KEMAMPUAN PEMECAHAN MASALAH MATEMATIS SISWA DALAM MENYELESAIKAN SOAL CERITA}

\section{Pendahuluan}

Pada masa perubahan, kita dapat melihat beberapa perkembangan yang sangat pesat diantaranya adalah, ilmu pengetahuan, teknologi dan sumber daya yang mampu bersaing yang mampu memiliki kualitas yang tinggi. Upaya yang mampu mendukung hal tersebut adalah dengan adanya sarana pendidikan. Pendidikan adalah sarana dalam mengembangkan potensi yang dimiliki sehingga mampu membentuk pribadi yang lebih baik yang harus diiringi dengan usaha yang giat. Dengan penguasaan ilmu pengetahuan serta keterampilan, maka seseorang akan mampu menjadikan bekal dalam mengatasi masalah dalam kehidupan sehari-hari.

Matematika adalah pembelajaran yang terdapat dalam komponen kurikulum di sekolah yang sebagai ilmu dasar dalam pembelajaran yang mampu memberikan efek yang besar dalam kehidupan sehari-hari. Hudojo dalam Wahyuddin, (2013: 1) mengemukakan bahwa "Dalam perkembangan modern, matematika memegang peranan penting karena dengan matematika semua ilmu pengetahuan sempurna”. Proses belajar di sekolah adalah suatu upaya yang mampu melatih tingkat berpikir siswa (kreatif, kritis, logis, sistematis dan lainnya) sehingga mampu dijadikan penunjang dalam pemecahan masalah dalam kehidupan sehari-hari dan mengembangkan kratifitas. Itulah yang menjadi salah satu penyebab bahwa pentingnya pelajaran matematika di semua jenjang pendidikan.

Penguasaan terhadap teknologi, keterampilan teknis dan ilmu pengetahuan yang memiliki hubungan di aspek ilmu adalah hard skill. Hard skill matematik pada peserta didik dimulai dari kompetensi inti hingga kompetensi dasar pada tingkatan kelas. Dalam Hendriana dkk. (2017: 1) mengungkapkan bahwa terdapat 8 jenis hard skill matematis diantaranya adalah kemamampuan memecahkan masalah, koneksi, berpikir kritis, berpikir logis, berpikir kreatif, pemahaman, komunikasi dan bernalar. Menurut kementrian pendidikan dan kebudayaan (2017: 10) bahwa "Pemecahan masalah adalah kemampuan yang memiliki korelasi dengan tujuan dalam pembelajaran khusunya matematika. Sedangkan Branca (Sumarno, 2010) mengungkapkan bahwa "Pemecahan masalah matematika meliputi beberapa aspek yaitu prosedur, strategi dan metode sebagai hal yang penting sekaligus utama pada pembelajaran matematika. Pemecahan masalah juga berkaitan dengan penalaran, proses berpikir dan penerapan pengetahuan.

Pemecahan masalah merupakan usaha dalam mencapai solusi dari suatu masalah 
sehingga kemampuan pemecahan masalah sangat dibutuhkan siswa dalam pembelajaran matematika karena memiliki korelasi dengan kehidupan sehari-hari, kemampuan tersebut dapat terlihat melalui pemahaman siswa baik dalam memilih prosedur strategi dan penerapannya (Hendriana dkk, 2017: 44). Soal cerita matematika adalah soal berbentuk uraian bukan soal hitungan biasa yang digunakan untuk mengetahui kemampuan peserta didik dalam memecahkan masalah sehari-hari Haji (Mahmudah, 2015:167).

Dari hasil observasi awal peneliti di sekolah, siswa kurang memahami masalah, sehingga apa yang ditanyakan pada soal tersebut tidak dapat diselesaikan dengan baik. Dalam menjalankan strategi siswa hanya bisa menjalankan apa yang dia ketahui dalam menyelesaikan soal, sehingga siswa tidak mampu memberikan kesimpulan pada soal.

Dalam pembelajaran matematika tentunya siswa harus mampu menggunakan prinsip ataupun prosedur dengan benar dan pemilihan yang tepat dalam menyelesaikan masalah matematika khususnya pada masalah sehari-hari. Hal ini sesuai dengan hasil observasi yang dilakukan peneliti, terlihat bahwa siswa mengalami kesulitan dalam menyelesaikan soal khususnya pada soal cerita, siswa tidak mampu menuliskan informasi yang tertera pada soal, tidak mampu merencanakan langkah selanjutnya dan tidak mampu menggunakan prosedur secara tepat sehingga tidak sesuai dengan hasil jawaban yang diinginkan.

Dari penjelasan tersebut, dapat diuraikan bahwa kemampuan pemecahan masalah dalam menyelesaikan soal cerita adalah kemampuan yang sangat penting sehingga dengan kemampuan tersebut siswa mampu mengupayakan mencari solusi terhadap masalah yang dihadapi. Hal tersebut menjadi suatu acuan sehingga peneliti bertujuan untuk mengetahui dan mendeskripsikan kemampuan pemecahan masalah matematis siswa kelas VIII SMP Negeri 1 Bangkala Barat dalam menyelesaikan soal cerita.

\section{Metode Penelitian}

Jenis penelitian ini adalah jenis penelitian kualitatif, yang berupaya untuk mengetahui kemampuan pemecahan masalah matematis siswa kelas VIII dalam menyelesaikan soal cerita. Penelitian ini dilakukan di SMP Negeri 1 Bangkala Barat pada tanggal 04 November 2020. Untuk menentukan subjek penelitian dilakukan dengan menggunakan teknik purposive sampling, yaitu cara yang digunakan untuk menentukan sampel berdasarkan pertimbangan tertentu dengan tujuan data selanjutnya dapat lebih representative (Sugiyono, 2018: 220). Subjek pada penelitian ini adalah siswa kelas VIII.B SMP Negeri 1 Bangkala Barat, yang difokuskan pada kemampuan pemecahan masalah matematis siswa dalam menyelesaikan soal cerita yang nantinya akan dibagi kedalam 3 kategori yaitu kategori tinggi, sedang, dan rendah. 
Adapun prosedur pemilihan subjek penelitian yaitu: (1) Memberikan tes kemampuan pemecahan masalah di kelas VIII.B SMPN 1 Bangkala Barat, (2) Menganalisis hasil pengerjaan siswa melalui tes kemampuan pemecahan masalah, (3) Mengelompokkan siswa dalam 3 kategori yaitu tinggi, sedang, dan rendah, (4) Melakukan wawancara kepada subjek penelitian untuk memverifikasi data hasil tes kemampuan pemecahan masalah siswa dalam menyelesaikan soal cerita. Instrument penelitian ini terdiri dari instrumen utama yaitu peneliti itu sendiri, dan instrumen pendukung yaitu tes essay kemampuan pemecahan masalah dan pedoman wawancara.

Untuk mengumpulkan data digunakan tes dan wawancara. Tes yang dilakukan adalah tes uraian (essay) dengan materi pola bilangan pada kelas VIII.B SMP Negeri 1 Bangkala Barat. Dari hasil tes uraian (essay) digunakan untuk mengetahui kemampuan pemecahan masalah matematis yang bebentuk soal cerita. Pemilihan subjek untuk dilakukan wawancara berdasarkan nilai tes tertulis dan kesediaan untuk diwawancarai selama penelitian. Wawancara dilakukan secara mendalam (In-depth Interview) terhadap beberapa subjek yang dipilih berdasarkan nilai tinggi, sedang, rendah uraian jawaban subjek. Dalam penelitian ini digunakan uji keabsahan data yakni dengan mengunakan triangulasi metode ialah pengecekan untuk mengetahui data kepada subjek yang sama dengan teknik yang berbeda yaitu melakukan tes kemampuan pemecahan masalah, dan wawancara. Jika terdapat hasil yang tidak sama maka peneliti harus mengkonfirmasi kepada sumber data guna memperoleh data lebih meyakinkan. Teknik ini diperoleh dengan melakukan tes kemampun pemecahan masalah dan pedoman wawancara. Teknik analisis data dalam penelitian ini menggunakan reduksi data, penyajian data, dan verifikasi atau kesimpulan.

\section{Hasil dan Pembahasan}

Berikut ini disajikan hasil tes dan petikan wawancara subjek kategori tinggi (KT). Data tersebut dipaparkan mengenai kemampuan pemecahan masalah matematis siswa dalam menyelesaikan soal cerita pola bilangan baik secara tulisan maupun lisan.
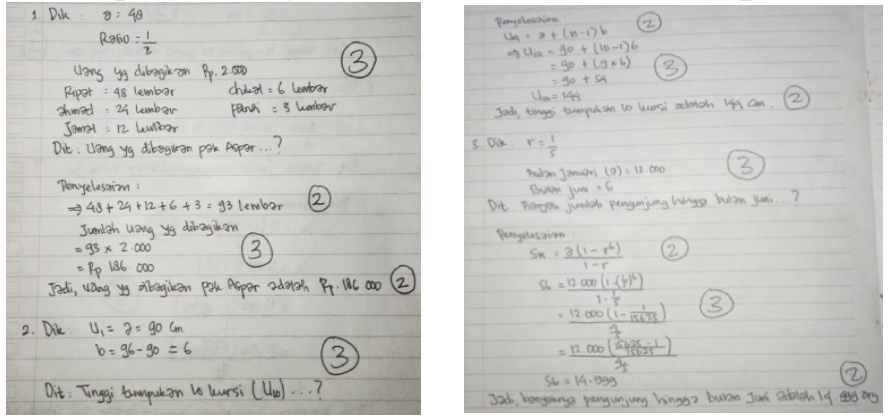

Gambar 1. Hasil Tes Kemampuan Pemecahan Masalah Subjek Kategori Tinggi 
Berdasarkan hasil tes dan petikan wawancara di atas, dapat dilihat bahwa dengan membaca soal sebanyak dua sampai tiga kali, subjek KT dapat mengetahui informasi awal dan hal yang ditanyakan pada soal. Berdasarkan hal ini subjek dapat memahami masalah secara tepat. Poin selanjutnya, subjek dapat menuliskan model matematika dengan menyusun perencanaan yang menghubungkan hal apa saja yang diketahui dan ditanyakan. Dari jawaban tes tertulis dan hasil wawancara, subjek dapat memaparkan rumus/persamaan yang dipakai untuk mengerjakan ketiga soal tersebut. Dalam perencanaan penyelesaian soal, subjek KT mampu mengerjakan dengan prosedur yang digunakan untuk menyelesaikan soal dengan benar. Tahap akhir, subjek membuat simpulan dari hasil akhir yang didapatkan dalam bentuk representasi berdasarkan pertanyaan pada soal cerita, kemudian membaca berulang untuk memastikan kebenaran jawaban yang didapatkan.

Berikut ini disajikan hasil tes dan petikan wawancara subjek kategori sedang (KS). Data tersebut dipaparkan mengenai kemampuan pemecahan masalah matematis siswa dalam menyelesaikan soal cerita pola bilangan baik secara tulisan maupun lisan.
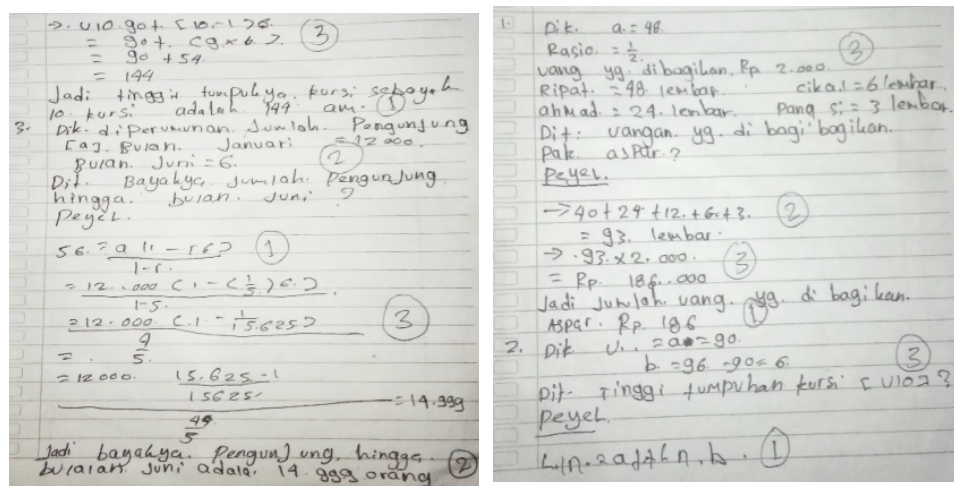

Gambar 2. Hasil Tes Kemampuan Pemecahan Masalah Subjek Kategori Sedang (KS)

Berdasarkan hasil tes dan petikan wawancara di atas, dapat dilihat bahwa subjek KS tidak menulis informasi secara sempurna hal yang diketahui dan yang ditanyakan dari soal. Setelah wawancara, peneliti mengonfirmasi kembali subjek KS dapat memaparkan model matematika yang di dalamnya terdapat beberapa variabel. Ini mengartikan bahwa subjek KS paham terhadap masalah dari soal cerita, akan tetapi tidak menuliskan dengan lengkap pada kertas jawaban dikarenakan kurang terbiasa. Selanjutnya dipaparkan pula bahwa peserta didik KS dapat menyusun dan menjalankan perencanaan. Pada wawancara sebelumnya tampak bahwa subjek KS tidak mempunyai cara lain dalam menyelesaikan soal. Hal tersebut tampak bahwa dalam menyelesaikan soal cerita pola bilangan, subjek KS hanya mampu menggunakan caranya sendiri.

Berikut ini disajikan hasil tes dan petikan wawancara subjek kategori rendah (KR). Data tersebut dipaparkan mengenai kemampuan pemecahan masalah matematis siswa dalam 
menyelesaikan soal cerita pola bilangan baik secara tulisan maupun lisan.
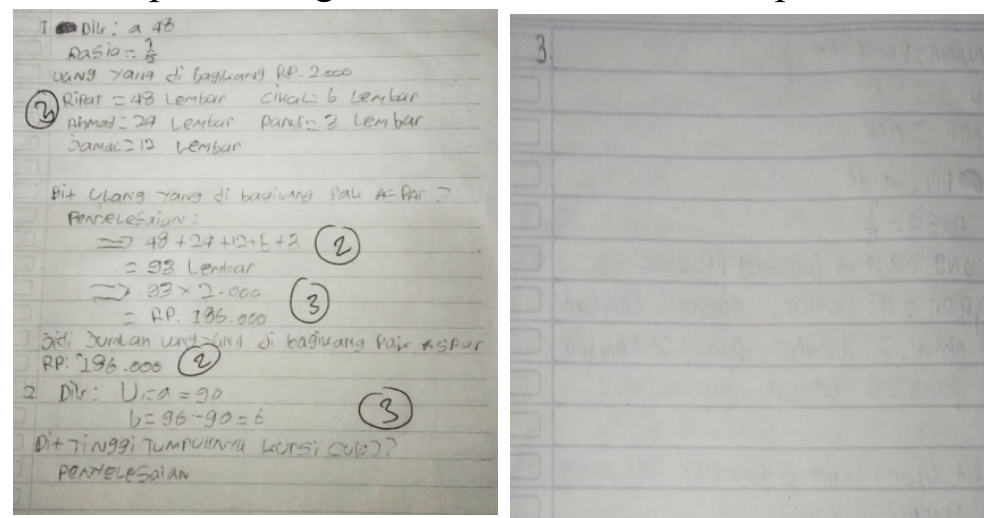

Gambar 3. Hasil Tes Kemampuan Pemecahan Masalah Subjek Kategori Rendah (KR)

Berdasarkan hasil tes dan petikan wawancara di atas, dapat dilihat bahwa subjek kategori rendah tidak dapat menuliskan jawaban berdasarkan indikator pada masing-masing tahap pemecahan masalah. Subjek KR tidak memahami soal yang diberikan secara baik, dan tidak dapat membuat perencanaan penyelesaian. Hasil wawancara yang didapatkan berupa data yang sesuai hasil tes. Subjek menyatakan bahwa ia tidak dapat memahami soal yang diberikan secara baik. Pada tahap wawancara didapatkan keterangan bahwa dalam mengerjakan soal cerita subjek (KR) kurang berlatih dengan soal seperti itu, terlebih pada soal pola bilangan. Berdasarkan hal tersebut pada soal pemecahan masalah, subjek (KR) termasuk pada kemampuan yang rendah dalam berlatih mengerjakan soal..

\section{Kesimpulan}

a) Subjek Kategori Tinggi (KT)

Untuk peserta didik dengan kategori tinggi dapat memahami masalah secara tepat dalam mengerjakan soal cerita pola bilangan, dapat membuat perencanaan penyelesaian dan mampu menjalankan sesuai tahap pemecahan masalah secara tepat juga dapat membuat kesimpulan dari jawaban yang didapatkan dalam bentuk representasi dan memeriksa kembali untuk memastikan kebenaran jawabannya.

b) Subjek Kategori Sedang (KS)

Untuk peserta didik dengan kategori sedang cukup baik dalam memahami soal, akan tetapi kadang lupa menuliskan salah satu hal yang diketahui atau yang ditanyakan pada soal cerita pola bilangan yang dikerjakan, dalam membuat rencana penyelesaian biasanya rumus/persamaan yang digunakan tidak sesuai dengan apa yang dikerjakan pada proses menjalankan rencana. Peserta didik kategori sedang juga dapat membuat kesimpulan dari jawaban yang didapatkan. 
c) Subjek Kategori Rendah (KR)

Untuk peserta didik yang berkategori rendah tidak dapat menjalankan langkahlangkah pemecahan masalah seperti memahami masalah, menyusun perencanaan penyelesaian, melaksanakan perencanan penyelesaian serta membuat simpulan pada penyelesaian soal cerita pola bilangan..

\section{DAFTAR PUSTAKA}

Wahyuddin. 2013. Pengaruh Kemampuan Berpikir Logis dan Kemampuan Verbal Terhadap Kemampuan Menyelesaikan Soal Cerita Matematika melalui Kemampuan Penalaran dan Komunikasi pada Siswa Kelas VII SMP Muhammadiyah Se-Kota Makassar. Tesis. Makassar: Universitas Negeri Makassar.

Hendriana, dkk. 2017. Hard Skills dan Soft Skills Matematik Siswa. Bandung: Refika Aditama.

Kementrian Pendidikan dan Kebudayaan. 2017. Buku Guru Matematika: SMP/MTs Kelas VIII.B. Jakarta: Pusat Kurikulum dan Perbukuan, Balitbang, Kemendikbud.

Sumarno. 2010. Berpikir dan Disposisi Matematik: Apa, Mengapa dan Bagaimana Dikembangkan pada Peserta Didik. (https://www.academia.edu/10346582/BERFIKIR_DAN_DISPOSISI_MATEMATIK_A PA_MENGAPA_DAN_BAGAIMANA_DIKEMBANGKAN_PADA_PESERTA_DIDI K, Diakses 06 Juni 2020).

Mahmudah, Siti. 2015. Peningkatan Keterampilan Menyelesaikan Soal Cerita Matematika Menggunakan Media Kartu Kerja pada Siswa Kelas II SDN Purworejo Kecamatan Kandat Kabupaten Kediri. Jurnal Pinus 1 (2). Diakses pada 15 Agustus 2020 (http://ojs.unpkediri.ac.id) Diakses 21 Juni 2020.

Sugiyono.2018. Metode Penelitian Kuantitatif, Kualitatif, dan R\&D. Bandung: Alfabeta. 